\title{
Yearbook of Medical Informatics
}
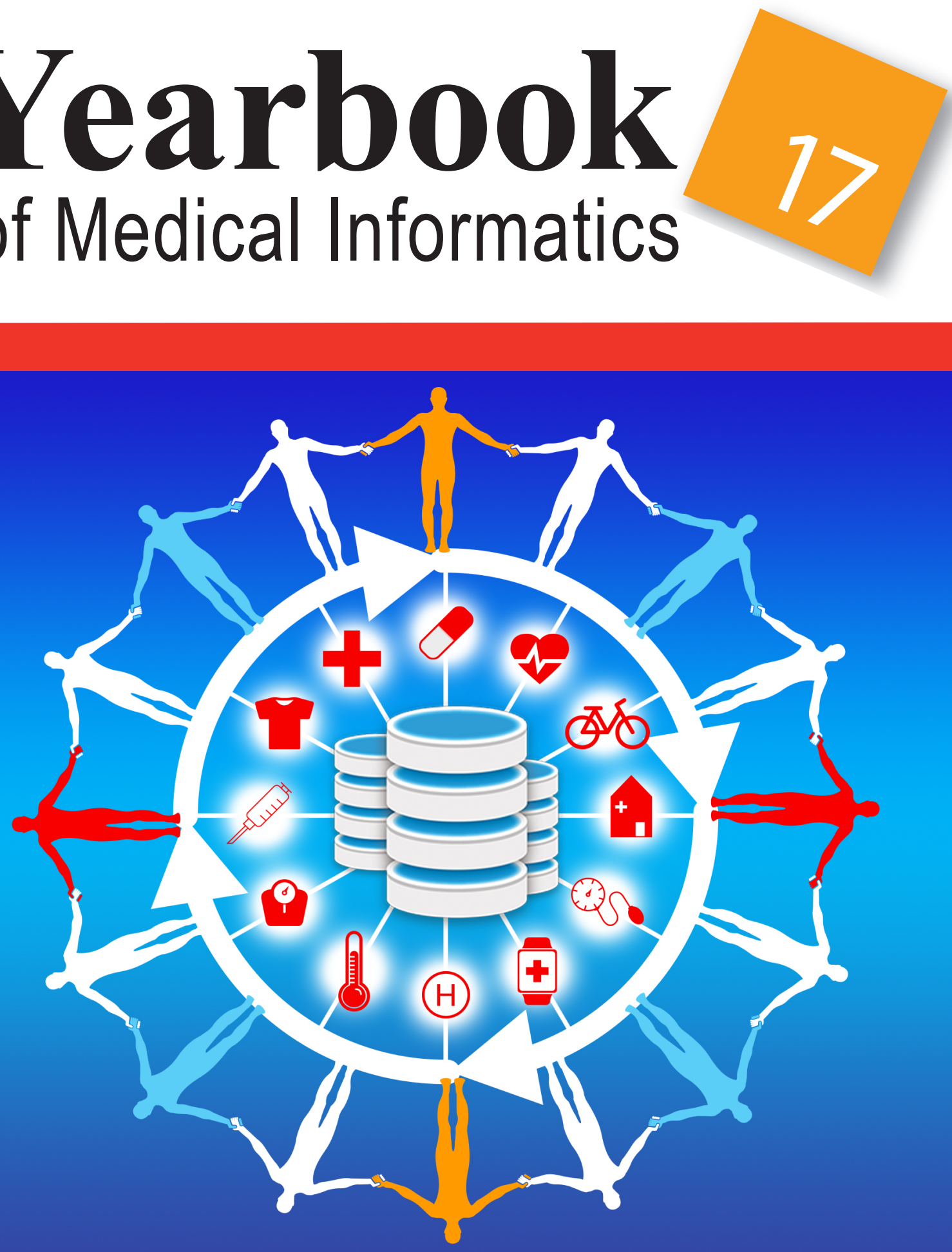

Learning from Experience:

Secondary Use of Patient Data

IMIA Schattauer 